Article

\title{
Combined Influence of Cutting Angle and Diameter Differences between Seedlings on the Grafting Success of Tomato Using the Splicing Technique
}

\author{
José-Luis Pardo-Alonso ${ }^{1}$, Ángel Carreño-Ortega ${ }^{1, * \mathbb{D}}$, Carolina-Clara Martínez-Gaitán ${ }^{2}$ \\ and Ángel-Jesús Callejón-Ferre ${ }^{1}$ (i) \\ 1 Department of Engineering, University of Almería, Agrifood Campus of International Excellence (CeiA3), \\ La Cañada de San Urbano, Almería 04120, Spain; jolupa@ual.es (J.-L.P.-A.); acallejo@ual.es (A.-J.C.-F.) \\ 2 Tenova, Technological Center: Foundation for Auxiliary Technologies for Agriculture; Parque Tecnológico \\ de Almería, Avda. de la Innovación, 23, Almería 04131, Spain; cmartinez@fundaciontecnova.com \\ * Correspondence: acarre@ual.es; Tel.: +34-950-214-098
}

Received: 11 November 2018; Accepted: 19 December 2018; Published: 21 December 2018

\begin{abstract}
Herbaceous crop yield intensification creates favourable conditions for the development of pests that intensify the attack of soil pathogens traditionally controlled by disinfectant, which are mostly prohibited and unlisted because of their toxicity. The use of grafted plants solves this problem and assists in addressing abiotic stress conditions. Within Solanaceae, specifically tomato crops (Solanum lycopersicum), the use of the splicing technique (simple and easily automated) is of special interest. This experiment attempts to present the combined influence of cutting angle and different random diameters on grafting success with the objective of detecting an optimum working range that will be applicable to automated and robotic grafting systems. An increase in the grafting angle is associated with a higher survival of grafted plants despite variations in diameter. Moreover, a threshold cutting angle is observed from which the success rate no longer increases but decreases drastically. Therefore, for a given working range with a significant cutting angle, whether the seedlings of origin are similar in diameter is not important, and this factor is more influential outside the optimal cutting angle range.
\end{abstract}

Keywords: tomato grafting; splice grafting technique; graft angle; random diameter

\section{Introduction}

The objective of the experimental study was to determine the combined importance of random rootstock and scion diameters at different cutting angles on splice grafting success. The proposed working hypothesis suggests that both parameters have a statistically significant relationship with grafting success and an optimum working range can be defined to achieve successful grafts.

The experiment was developed as part of a larger study to optimize working conditions for the automation of grafting via the splicing technique. The study is autonomous and independent and presents sufficient and consistent results for the definition and specification of the splice grafting conditions that provide the most optimal results, whether performed manually or automated.

Grafting can be defined as a natural or deliberate fusion of plant parts by which vascular continuity is established [1], so that the resulting organisms function as a single plant [2].

The portion of the upper tissue or crown of a plant, which is also known as the stem or scion, adheres to another portion of the plant, specifically its root and lower part, which is commonly called rootstock, under stock or stock, and both parts come in contact and join with each other so that the resulting composite plant grows and develops as a single organism (graft). The callus corresponds to 
the mass of parenchyma cells that develop from the plant tissue of the scion and the rootstock around the wound and where the development of vascular connections of the resulting graft union occurs [3].

Reducing the impact of pathogens is a challenge in all agricultural production systems [4], and monocultures are even more vulnerable than more diversified agricultural production systems [5]. Thus, grafting has become a tool of enormous potential to quickly enhance the efficiency of modern vegetable cultivars to promote wider adaptability or resistance to different stress situations [6].

The sequence of structural and biological events that occur in the development of a compatible graft between plants has been described in many studies, and the following development pattern is observed in which three fundamental phases can be distinguished: fusing of the rootstock and scion; proliferation of the callus around the union; and vascular re-differentiation through the interface establishing continuity between rootstock and scion $[1,3,7,8]$ :

1. The meristematic tissues of the stem are placed in direct contact with the tissues of the rootstock. Once both components of the graft are in intimate contact, cambium cells from the rootstock and the scion produce parenchyma cells that fuse forming a callus tissue [9]. This first phase of cohesion that forms the callus is a reaction similar to wound healing, and it does not require recognition between rootstock and scion, occurring in both compatible and incompatible grafts.

2. If the graft is compatible, a differentiation of certain vessels and sieve tube elements of the phloem is observed in the callus, and they are not derived from the cambium and constitute the first transitional and continuous union between the rootstock and the scion.

3. In the last part of the grafting process, the cambium layer newly formed in the bridge of the callus begins its own meristematic tissue activity, thus forming new vascular tissue. Production of these new vascular elements that join xylem and phloem allows establishing a symplastic communication between rootstock and scion [1].

The success of the graft performed with a variety of compatible seedlings is determined by the three events previously described, assuming an important role of the plant hormones related to growth, such as auxin, in the grafting process [10]. Thus, the graft may originate from a combined mechanism of wound healing and conductive vessels formation [11]. Therefore, vascular connection is the last event in a successful healing process and represents the most important event because once such a vascular connection is established, water and solute transport begins from the stock to the scion, and the mechanical strength at the graft union increases [7,12]. One difficulty is to understand when the grafting process is completed [13], since a simple technique for continuous evaluation of graft development is not available [14]. Nonetheless, the assessment can be based on various techniques, including destructive and non-destructive techniques as follows:

(1) Visual estimation of the constituent seedlings and the appearance of graft growth [15]; (2) thermal camera imagery because the temperature of the leaves is 2 to $3{ }^{\circ} \mathrm{C}$ lower than that in a failed graft due to the transpiration of a successful graft [16]; (3) vertical cut performed on the graft surface and observation of the curvature of the vascular system formed at the union [17]; (4) measurement of the electrical resistance transferred from the scion to the rootstock through the surface area of its connection, which undergoes variations associated with histological changes during the union of the rootstock and the scion [14]; (5) assay performed to evaluate the tensile strength of the graft and analyse the strength of the graft union between rootstock and scion until breaking [18,19]; (6) displacement transducers used to perform a continuous and non-disruptive evaluation of the functional hydraulic connections within the plant [20]; and (7) NMR-based method (Nuclear magnetic resonance), that reveals water flux vectors inside individual vessels of intact plants [21].

The tomato is one of the world's most important herbaceous crops [22], and grafting of tomato plants is a widespread practice. Grafting methods among seedlings vary greatly and considerably depending upon the type of crops, farmer's experience and preferences, availability of facilities and machines, the number of grafts to perform and even the purpose and destination of the grafts, i.e., whether they are for the farmer's own uses or for sale and commercial distribution [23]. Grafting is 
a common practice among herbaceous crops, and its use for Solanaceae is highlighted as follows: cleft or split grafting [21,24], splice or tube grafting [25,26], plug-in grafting [27], double-stem grafting [28,29], or pin grafting [15,30], among others.

Splice grafting, also known as tube grafting, top grafting or slant cut grafting, is the most popular [31] and widely used technique for tomato as well as eggplant [32]. The rootstock is cut below the cotyledons, thus eliminating the need to continually eliminate the sprouting of the stock over the plant's life [33]. The scion is also slant cut on a complementary angle above the cotyledons. Both parts are then placed in contact and secured by means of a tube or elastic tube-shaped clip with side slit. This method has the disadvantage of being highly demanding in terms of post-grafting microclimatic conditions, which require meticulous timing and delicate handling after the cut until healing and the maintenance of optimal temperature and humidity conditions to stimulate rooting [34]. As an advantage, the splicing method allows grafting with smaller plants, which reduces the pre-graft cultivation time and takes up less space in cultivation chambers and nurseries [35].

Velasco [12] and Villasana [36] affirmed that successful grafting is contingent upon similar stem diameters and the alignment of the vascular cambium area. However, such claims are dependent on the effect that the seedling diameter variable has on grafting success and do not consider the interrelated influence of other parameters and constraints of the grafting process.

For studying the success or failure of splice grafting, Yamada [37] established three factors of importance for its execution: (a) area of the cut surface; (b) gripping force of the union clip; and (c) smoothness of the cut surface and sharpness of the blade. For the first factor, allusive to the coincidence rate between seedlings, from coincidences of $50 \%$ graft successes of over $85 \%$ were achieved, and up to $95 \%$ success rates were observed for alignments over $80 \%$; all this referred exclusively to a test angle of $30^{\circ}$, so these results were obtained regardless of the effect of the cutting angle on the success of the process.

Furthermore, although the number of vascular bundles does not affect the grafting success, differences in diameters between the rootstock and the scion [38], that mark the alignment between them do have an effect. Thus, when a graft is performed, it is important to increase the chances that the vascular bundles from the rootstock and the scion come in direct contact, maximizing the area of the cut surfaces that are joined by pressing them together [39].

For manual and automated grafting, the alignment of diameter of both seedlings must be identified, classified, and visually paired. This is an expensive and arduous task that applies a series of calibrations and visual comparison criteria based on morphological characteristics, which may be subjective and susceptible to human error $[40,41]$. The present study analyses the importance of these pre-grafting tasks based on grafting success and whether an optimal working zone can be established that guarantees adequate grafting success without having to pre-sort the seedlings.

\section{Materials and Methods}

\subsection{Definition of Operating Conditions}

The experimental study was carried out at the Tenova Technological Center: Foundation for Auxiliary Technologies for Agriculture (Centro Tecnológico Tecnova: Fundación para las Tecnologías Auxiliares de la Agricultura) in Almería between March and June 2017. Almería's surroundings correspond to a model of agricultural exploitation of high technical and economic performance of greenhouse herbaceous fruit crops, especially for the tomato crop (Figure 1). 


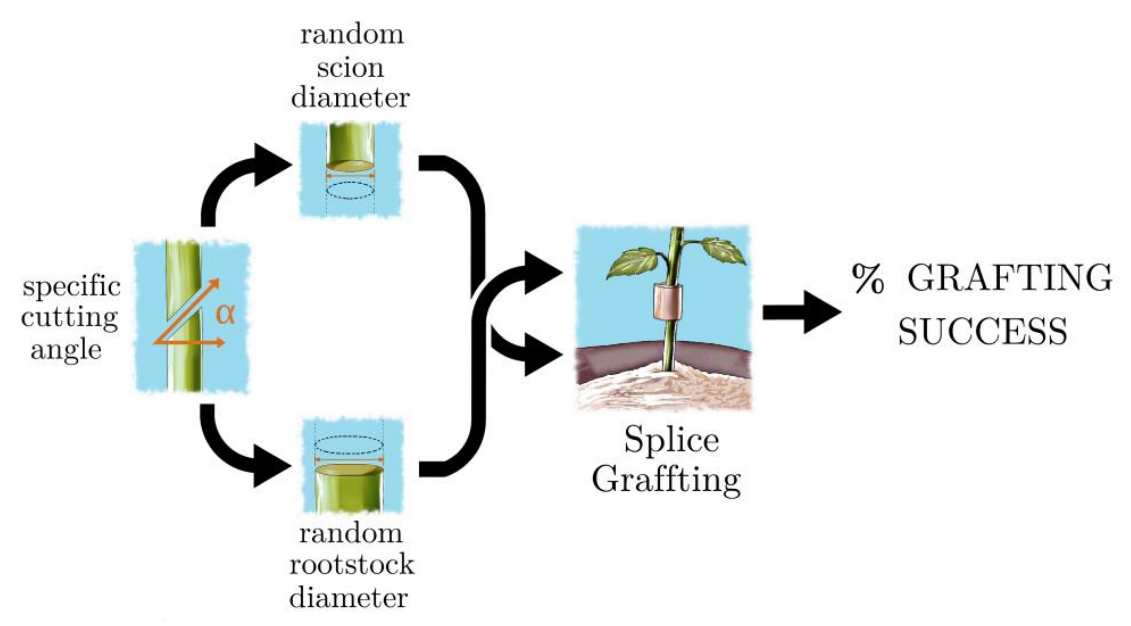

Figure 1. Working procedure of the experimental study to determine the combined importance of random rootstock and scion diameters at different cutting angles on splice grafting success.

For the study, rootstocks of the interspecific hybrid KNVF (L. esculentum $x$ L. hirsutum) were used since it is the most used stock for tomato grafting [42-44]. The commercial rootstock Maxifort was used because of its strong roots and vigour and good performance at lower temperatures and in high salinity conditions. It presents high resistance (HR): ToMV: 0-2/Fol: 0,1/For/PI/Va: 0/Vd: 0; intermediate resistance (IR): $\mathrm{Ma} / \mathrm{Mi} / \mathrm{Mj}$ [45]. Likewise, the Ventero variety has been used as a grafting scion as an indeterminate tomato hybrid for truss harvesting, and it presents medium vigour, with good foliar coverage, very uniform fruits, slightly flattened of good red colour and deep shine, very good cracking and micro-cracking tolerance, and compact and well-formed clusters. It presents high genetic resistance (HR): ToMV: 0-2/Ff: B, D/Fol: 0,1/Va: 0/Vd: 0; and intermediate resistance (IR): TYLCV/Ma/Mi/Mj [39]. Both varieties are commonly used for manual grafting using the "tomato on tomato" (ToT) splicing technique, which demonstrated their compatibility prior to the experiment.

The working environment during the study was maintained under stable and controlled environmental conditions throughout all grafting experiments, with temperatures oscillating between $20^{\circ}$ and $25^{\circ}$, relative humidity conditions occasionally forced between $75 \%$ and $90 \%$ and stable brightness conditions of natural in-direct light. Oda [39] indicated that grafting must be performed in the shade in an area protected from the wind and the sun to avoid wilting of grafted seedlings. Grafting was performed at the lowest period of plant transpiration during morning hours [46], between $8 \mathrm{~h}$ and $12 \mathrm{~h}$ to maintain transpiration similar among the experiments and the time period when the transport of water from the roots to the leaves is slowest, which makes the graft less susceptible to water stress and therefore to water loss. Other parameters with possible influence, such as atmospheric $\mathrm{CO} 2$ and other air contaminants, were not been controlled.

In the nursery, the plants were cultivated and attended to from sowing until 25 to 35 days after, and the scions were sown 2 to 5 days before the rootstock seeds. This variability of days is determined by the growth rate since different plants require different germination periods [47], and such periods are directly related to climatic conditions of the month of growing.

For the experiment, the plants were considered mature and ready for grafting when they had 2 to 4 well-defined true compound leaves [32], preferably with little foliage, thus decreasing the transpiration demand and post-grafting stress. The peat root ball remained wet but not soggy at all times during the grafting process, thus ensuring proper root respiration. The substrate used was $80 \%$ black peat with $10 \%$ perlite and $10 \%$ mulch. The experiments were always conducted with seedlings whose stems were still green and tender (herbaceous and non-woody). 
For the splicing method, the seedling stems diameters should be at least $1.5 \mathrm{~mm}$ [48], and not too thick but with some natural and random variation. In the study, the diameters in the area close to the cut have varied from 1.5 to $2.5 \mathrm{~mm}$ for the scion and 2 to $3 \mathrm{~mm}$ for the rootstock.

The matching of the rootstock and scion samples was established randomly among plants that were healthy, had an acceptable anatomy and growth and presented diameters between the established reference limits. Seedlings with anomalous growth and diameters outside the established range were discarded. Diameters were measured using a digital calliper with a resolution of $1 \mathrm{dmm}(0.1 \mathrm{~mm})$ and repeatability of $1 \mathrm{dmm}$ in the areas close to where the cut was performed both for the rootstocks and for the scions. The cut in the rootstock was always performed below the cotyledons, whereas the cut in the scion was performed above the cotyledons.

The complete experiment consisted of 10 individual events of 150 grafts each distributed over 4 months. Each graft consisted of 10 series of 15 grafts per tested angle. Therefore, 10 representative angles of the possible cutting range were selected: $0^{\circ}, 10^{\circ}, 20^{\circ}, 30^{\circ}, 40^{\circ}, 50^{\circ}, 60^{\circ}, 70^{\circ}, 80^{\circ}$ and $85^{\circ}$. Once each of the experiments was performed, grafts were grouped for healing on a single grafting tray of $15 \times 10$ cells, placing each group of grafts of a given angle in each of the 10 rows of the tray. Each of the grafted plants was rotated within their row for every tested angle eliminating in this way the position factor and its possible effects (ventilation and luminosity among others).

\subsection{Device Description}

For the experiment, two seedling-cutting machines were implemented to ensure the accuracy of the cutting angle required for each test and the integrity of the dissected seedling. The machines were similar and complementary to each other, where one was designated for cutting the rootstock and the other for cutting the scion. Each of the machines had a double acting dual rod cylinder, model CXSM15-15 by SMC, which operated at 3.5 bars and used dry-pressed air to produce a clean bisection of the seedling via a stainless steel cutting blade (type BA-160-9 $\mathrm{mm}$ from NT Cutter) that can be attached as a tip and is interchangeable with an adjustable inclination angle, thus providing optimal sharpness (Figure 2). To ensure a clean cut, the machine has a fitting notch adapted to accommodate the seedling, ensuring the verticality of the stem ahead of the blade and another notch fitted for the blade at each cutting angle. The blade was replaced prior to each experiment (150 grafts per blade), and it was below the limit of 5000 grafts per blade established by Yamada [35], who determined that as the number of cuts per blade increases, the roughness of the cutting area becomes notable, thus reducing the grafting success. Before each use, the blade was cleaned and disinfected as Bumgarner suggests by soaking in alcohol [45], exposure to flame and air drying.

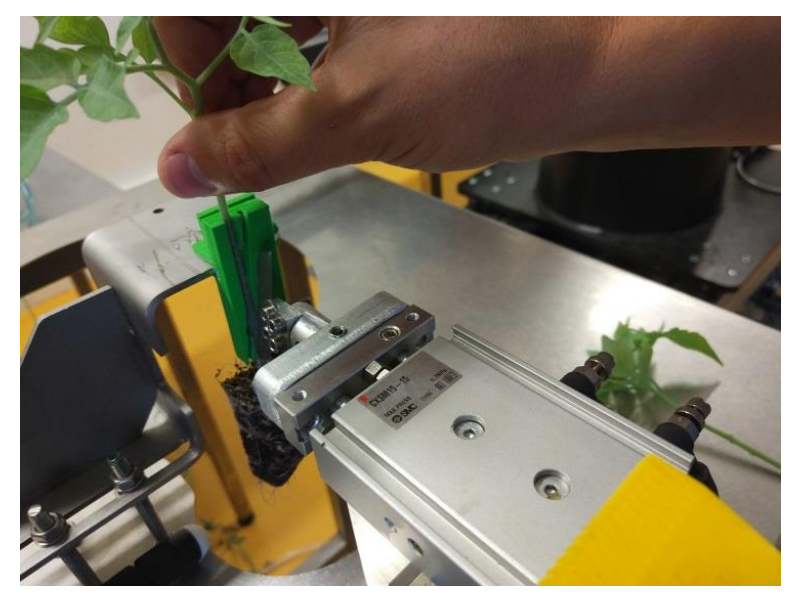

Figure 2. Cutting device. As can be seen, a fitting device is used to guarantee or ensure the verticality of seedling in the cutting process, beside a groove for insertion of the cutting blade. A specific fitting device for each cutting angle was developed. Once inserted, the seedling is disectioned in two by a sharp blow of the sharp blade. 
The union of the seedlings cut by the machines was executed manually using the traditional splice grafting technique described by Oda [49] and expanded on by DeMiguel [33]. For this, plastic grafting clips of different lengths were used according to the tested angles. Clips were cut from a continuous flexible transparent plastic roll and outfitted with lateral wings for opening and placement to allow for easy observation of the success or failure of the graft. The clip diameter was less than $3 \mathrm{~mm}$, and the shape was slightly oval, which guaranteed a better grip when the rootstock and scion diameters were unequal. Grafting clips that were too long inhibited the attached graft union, and clips that were too short exerted too much pressure and deformed the graft union [50].

Manual handling of the seedlings was always performed after thorough washing with antibacterial soap. Direct contact with the wounds was constantly avoided. Once grafted, the plants were placed on the tray and introduced into a healing chamber, similar to a small acclimatization tunnel as described by Oda [51]. This chamber was itself placed inside a larger growth chamber that allows for the appropriate basic environmental conditions as follows: $14 \mathrm{~h}$ photoperiod and a daily light integral (DLI) of $\approx 100 \mu \mathrm{mol} \cdot \mathrm{m}^{-2} \cdot \mathrm{s}^{-1} \mathrm{PAR},(\sim 3000 \mathrm{Lux})$ of indirect diffuse light during the callus development stage [52,53], temperature of $26^{\circ} \mathrm{C}$ and relative humidity of $95 \%$.

After the trays were transferred to the chamber, the plants were not manipulated or moved for 3 full days so that the natural healing process was not disturbed. From the fourth day of the graft, the first individual plant by plant visual inspection was conducted inside the chamber. This inspection was routinely repeated during the following days from the $4^{\circ}$ DAG (day after the graft) until the $9^{\circ}$ DAG to assess changes and the healing process in each plant and therefore the success or failure of the graft. During this period and from the $6^{\circ} \mathrm{DAG}$, the environmental conditions of the chamber were gradually relaxed, acclimatising to external environment, and the inside chamber was opened to decrease the humidity and temperature, acording to outside. Between the $10^{\circ}$ DAG and the $14^{\circ}$ DAG, the plants were eventually removed from the growth chamber and allowed to develop without being transplanted.

While the rootstock and scion establish a vascular connection during the first days [54], at least 14 days are needed for the graft union to heal completely and be considered functional. After 14 DAG of performing daily observations for each experiment, the experiment was ended. Grafts that did not survive the healing process within the stipulated period were considered failures.

The success or failure of the graft has been evaluated by daily visual estimations and observations that evaluated the development of the graft and analysed other external symptoms and evidence, such as physiological abnormalities or signs of wound healing and scarring. Symptoms of internal failure generally precede those of external failure [55]. If the graft is successful, evident progress is generally seen from the wilt stage to greater vigour in the aerial part of the graft, which is reflected in a palpable recovery and associated with a gradual disappearance of signs of dehydration, which implies that adequate vascular continuity has been generated among the elements of the xylem. In addition, this factor is accompanied with the occurrence of axillary buds in the aerial part, thus indicating that the graft is successful and the resulting plant is functional. These factors are used to determine whether the graft is successful. Regardless, the behaviour and subsequent evolution of the grafts continue to be evaluated until 14 DAG to corroborate and validate the evolution of the natural healing process of the graft (Figure 3). 


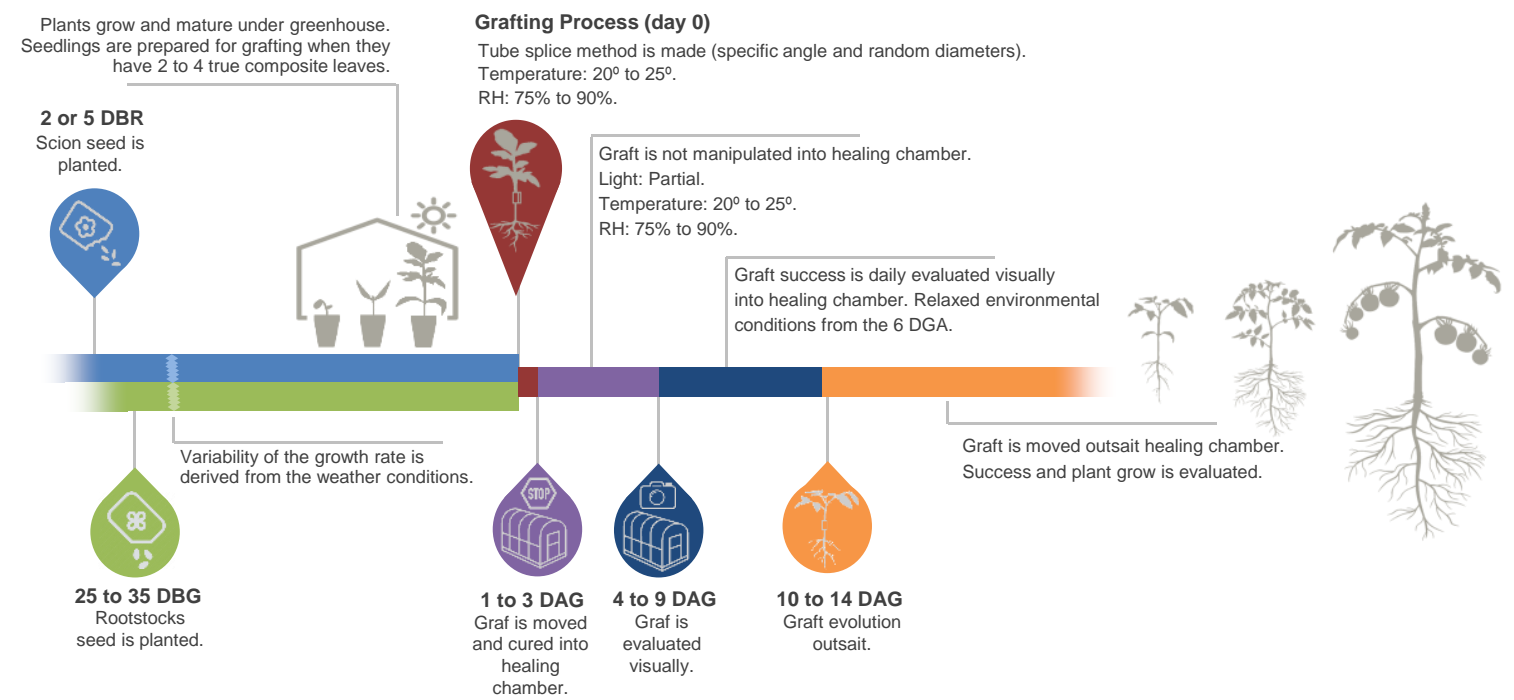

Figure 3. Timeline of the grafting process developed. DBR (days before rootstock has been planted). DBG (days before grafting process). DAG (days after grafting process).

\section{Results and Discussion}

The results of the 1500 individual experiences were collected and grouped polytomously in 10 sections of equal height to compare the cutting angle and differences in diameter of rootstock and scion and to evaluate the grafted plant survival for each case.

The data analysis process included two stages: the first phase consisted of conducting a descriptive analysis of the data distribution and their correlation through the application of One-way ANOVA for Randomized Complete Block Design (RCBD ANOVA), and the second phase consisted of a two-way analysis of variance in which only one sample per group was run, and the results were then assessed by a post-hoc comparison test, such as Student's $t$-test.

\subsection{Data Analysis: Descriptive Statistics}

An analysis of the experimental results showed that the effect of variations in diameter on the grafting success decreases as the grafting angle increases, and the differences are nearly negligible in the range between $50^{\circ}$ and $80^{\circ}$ and between $60^{\circ}$ and $80^{\circ}$, where percentage changes between the grafted seedling and the successful graft were maintained at an overall success rate of greater than $90 \%$ or even greater than $95 \%$, respectively. This finding confirms that for greater angles, the success probability depends less on the diameter of the seedlings. From $80^{\circ}$ onward, successful execution of the graft began to be materially more complicated due to two factors: physical limitations related to the technology used for the cutting and subsequent union of the seedlings; and the exponential increase in the sectioned surface that was directly related to the tangent of the cutting angle, which determined both the exposed surface and the rigidity and firmness of the structure of the dissected and subsequently joined seedlings.

Grouped data confirm that independent of section variation among the seedlings of origin, a working zone between $50^{\circ}$ and $80^{\circ}$ offers good results in terms of graft success (Figure 4). 


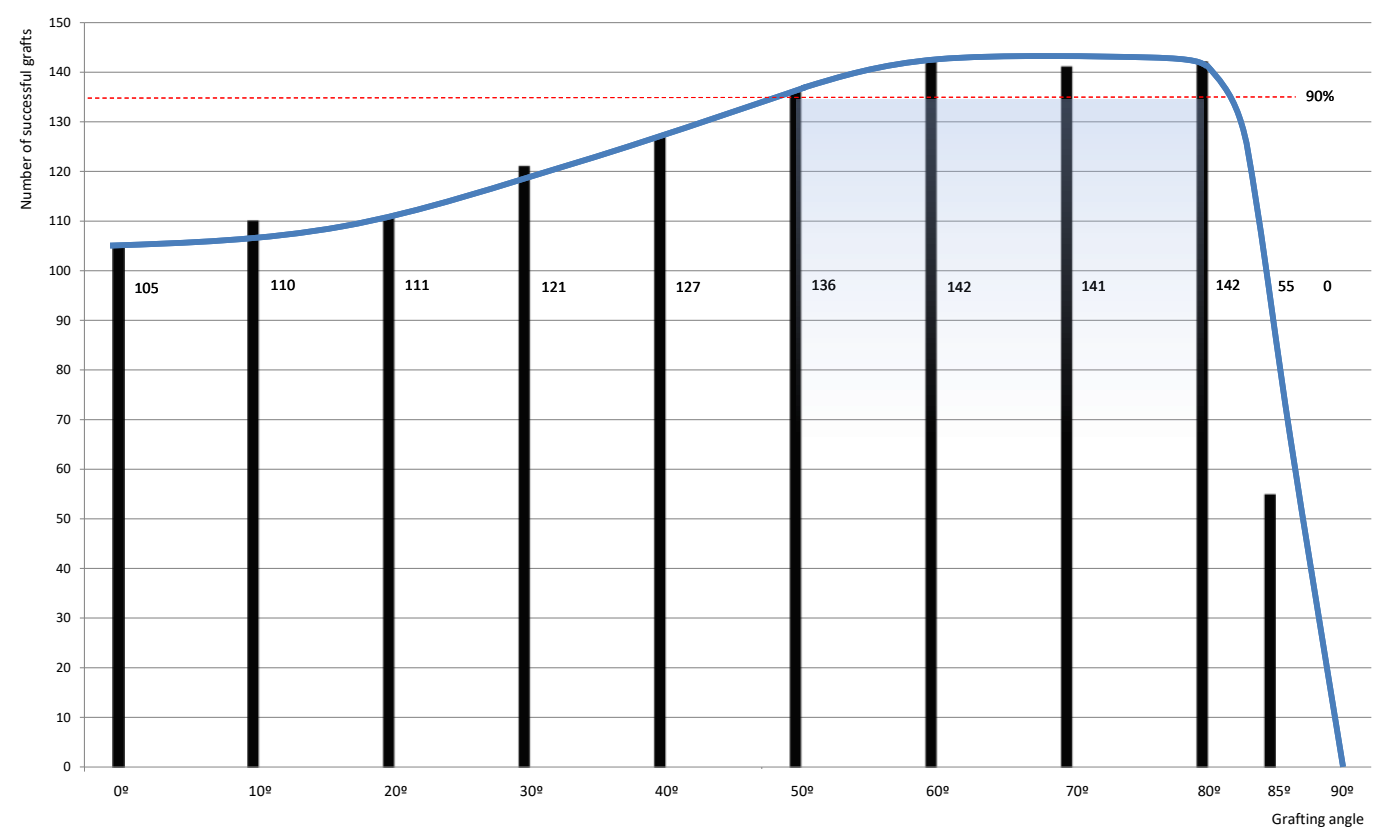

Figure 4. Distribution of successful grafts according to different cutting angles. It can be seen that the zone between $50^{\circ}$ and $80^{\circ}$ (blue zone), has a success rate higher than $90 \%$, so we can consider it an optimal work zone. This graph represents the absolute number of successes for each cutting angle, without considering the variable of difference between diameters.

Having studied the diametric differences with respect to grafting angles, it is apparent that at small cutting angles and with highly variable diameters, the failure probability is high, and success was not observed, while at larger cutting angles, success associated with high diametric differences was recorded. A slightly greater range between quartiles is observed at angles between $50^{\circ}$ and $70^{\circ}$, which indicates a greater tolerance to variable diameters during the grafting process (Figure 5).

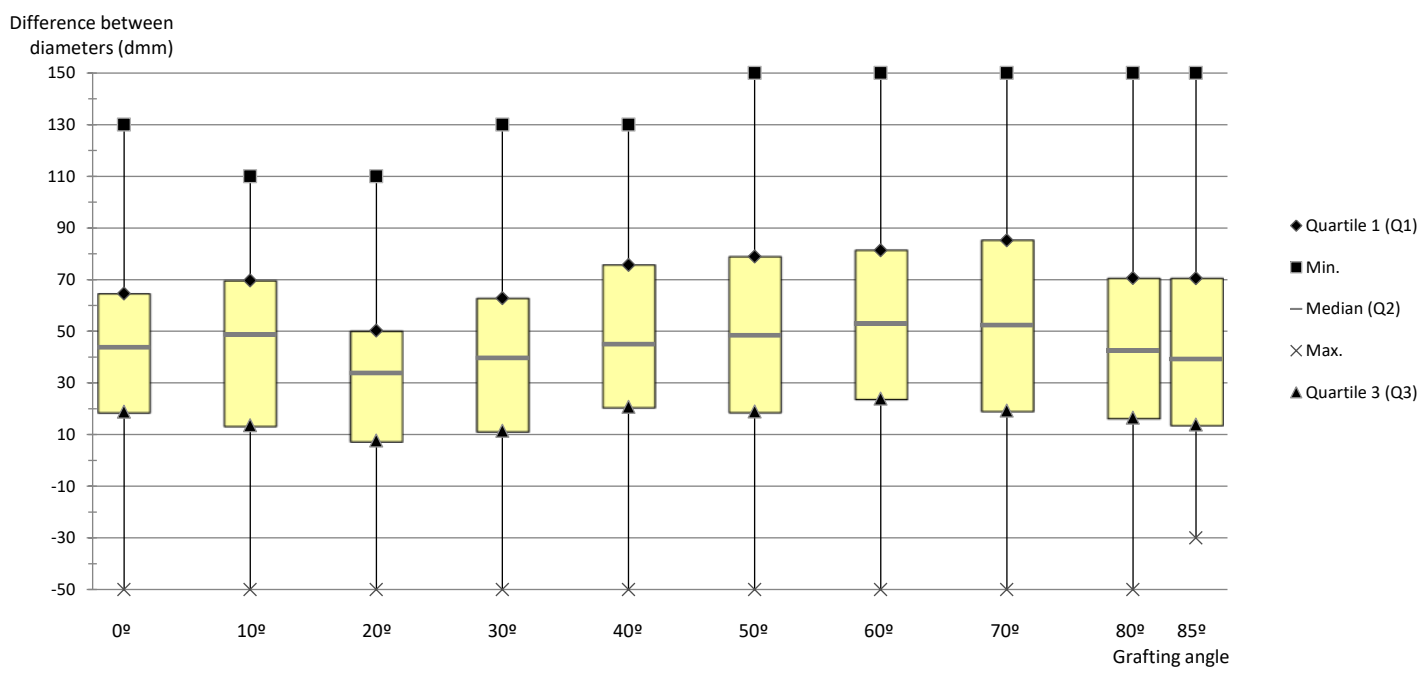

Figure 5. Distribution of successful grafts according to the differences between diameters of plants for each angle of union. This graph represents the density function of successes for each cutting angle $\left(1 \mathrm{dmm}\right.$ is a tenths of a millimeter, $\left.10^{-4} \mathrm{~m}\right)$. A slightly greater amplitude between quartiles is appreciable at angles between $50^{\circ}$ and $70^{\circ}$ degrees, which indicates a greater tolerance in this range to the disparity of diameters.

The combined representation of cutting angle and diameter differences between plants versus the success of the graft provide evidence of the combined effect that both factors have on the successful 
execution of the graft. This representation has been developed through the use of the software Surfer12 and the Local Polynomial gridding method for the interpolation of points of the spatial matrix, which only uses points within the defined neighbourhood and adjusts the matrix to a first-order polynomial to the power of two. Polynomial interpolation allows us to create a uniform surface and identify long-range trends in the data set (Figure 6).

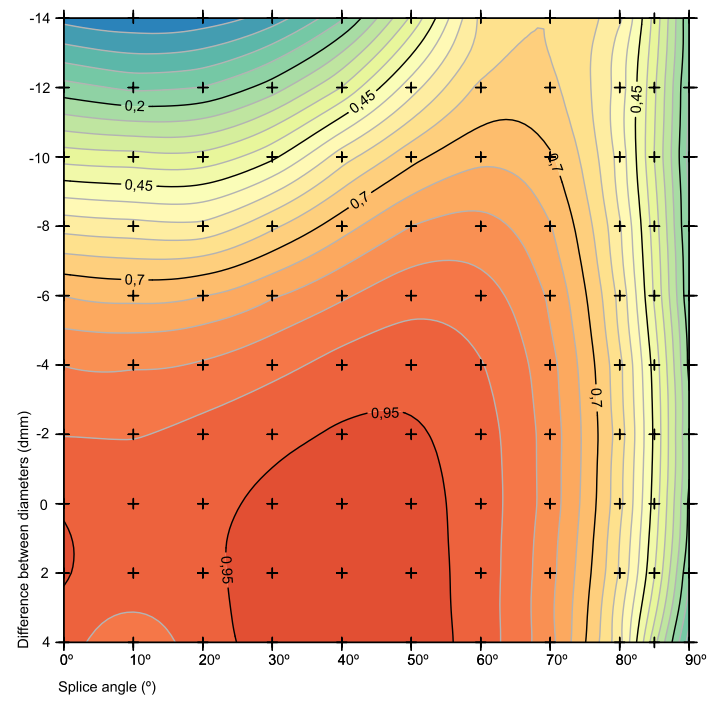

(a)

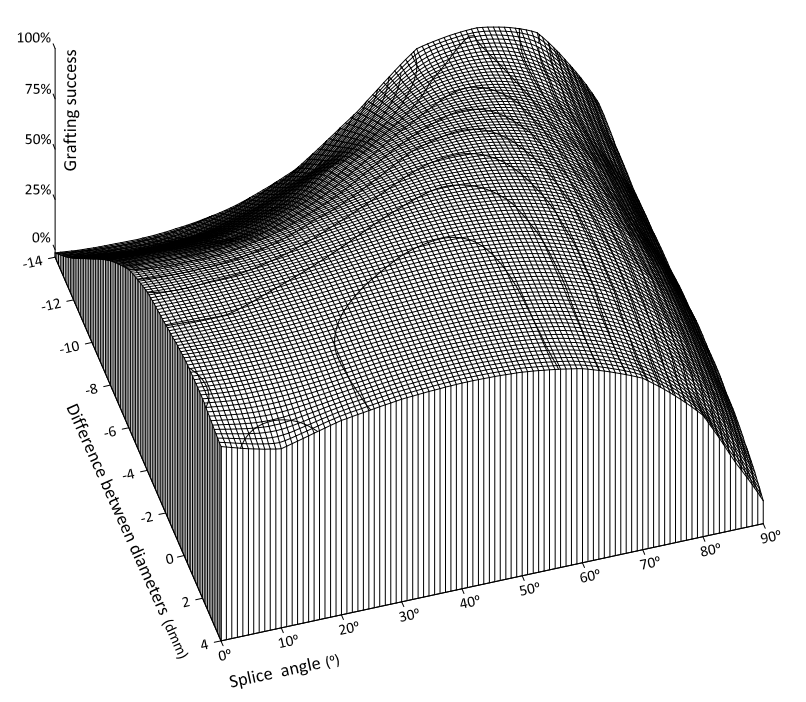

(b)

Figure 6. Graphical representation of the combined influence of cutting angle and diameter differences between seedlings on the grafting success of tomato using the splice grafting thecnique. These graphs represent the successes for each concrete difference of diameters, associated to each angle of union ( $1 \mathrm{dmm}$ is a tenths of a millimeter, $10^{-4} \mathrm{~m}$ ). Results represented by the Local Polynomial Gridding Method (Polynomial Order 1, Power 2). (a) Coloured contour diagram of successful grafts (\%), as a function of cutting angle $\left(^{\circ}\right)$ and difference between diameters of grafted $(\mathrm{dmm}) ;(\mathbf{b}) 3 \mathrm{D}$ wireframe of successful grafts $(\%)$, as function of cutting angle $\left(^{\circ}\right)$ and difference between diameters of grafted (dmm).

At small differences in diameter, the success rate is high for cutting angles between $30^{\circ}$ and $60^{\circ}$, whereas when this difference between diameters increases, the maximum values move to values between $50^{\circ}$ and $70^{\circ}$, and the percentage of success gradually decreases.

One of the possible causes that justify grafting success within this range of working angles is the exponential increase of the contact surface, which increases in equal measure the possibility of matching between vascular bundles arranged in a circle around the stem [34]. Effective contact depends on the surface and arrangement of the bundles in the two plants that are grafted; therefore, at a larger cutting surface with an appropriate arrangement and matching of the seedlings, a greater area of contact is observed. Thus, this range of graft angles between $50^{\circ}$ and $70^{\circ}$ is associated with a decrease in failure and substantially less importance and influence of uniformity in stem diameter between both plants on grafting success.

By increasing the difference between the sections at the point of union and at greater graft angles, the area of contact surface increases exponentially, thus increasing the probability of vascular correlation. Moreover, for uncovered surfaces, the area remaining outside the contact area is exposed to pathogens, such as bacteria and fungi, which cause the graft to fail [56]. In addition, greater stress associated with scarring is evident based on the proliferation of a larger callus in response to the wound. As the cutting angle approaches $90^{\circ}$, the successful execution of the graft begins to become more mechanically complicated due to the technology used in the process and the firmness of the 
dissected seedling themselves. In addition, the uncovered or unmatched surface between the seedlings increases excessively.

Therefore, when significant differences in diameter occur between the rootstock and the scion, the probability of failure is higher at small cutting angles close to horizontal, while the probability of success is higher at similar diameters. This correlation reflects the farmer's own practice and experience and represents a frequently observed factor that is directly related to the success of the graft as observed in the first known publication referring to seedling grafting for herbaceous crops, which indicated that seedlings with similar diameters should be selected [57]. However, subsequent studies have corroborated the direct relationship between the cutting angle and the success of the graft [19], which supports the premise that seedlings should have similar diameters in the cutting zone. Zhao [58] stated that expanding the area of contact between the rootstock and scion is the key to graft survival.

\subsection{Data Analysis: ANOVA}

The experimental results for grafting success were tested via two-way ANOVA of the cutting angle and diameter difference, where each of these factors has been grouped into 10 blocks, with a single sample or repetition per group (ANOVA). The randomized complete block design (RCBD ANOVA) analysis technique used as the usual standard for agriculture was used, where similar experimental units were grouped into blocks. We consider $\alpha=0.05$ (95\% confidence level). The statistical package Real Statistics Resource Pack 5.8 in Microsoft Excel 2010 was used for the study. Analysis of variance was performed to answer the following general research question (RQ): Are statistically significant differences observed between the means of grafting success for different cutting angles and different diameters between seedlings? (Tables 1 and 2).

Table 1. Analysis of variance of two factors without replication. Factor 1: the difference between the rootstock and scion diameters, where the positive values represent a larger diameter of the rootstock and the negative ones a larger diameter of the scion. Factor 2: cutting angles of the seedlings.

\begin{tabular}{ccccc}
\hline \multicolumn{5}{c}{ Analysis of Variance of Two Factors without Replication } \\
\hline Summary & Count & Sum & Mean & Variance \\
\hline 15 to $13 \mathrm{dmm}$ & 10 & 3.3333 & 0.3333 & 0.1806 \\
13 to $11 \mathrm{dmm}$ & 10 & 3.7242 & 0.3724 & 0.1253 \\
11 to $9 \mathrm{dmm}$ & 10 & 5.8789 & 0.5879 & 0.1009 \\
9 to $7 \mathrm{dmm}$ & 10 & 7.1258 & 0.7126 & 0.0589 \\
7 to $5 \mathrm{dmm}$ & 10 & 8.4487 & 0.8449 & 0.0545 \\
5 to $3 \mathrm{dmm}$ & 10 & 9.0306 & 0.9031 & 0.0202 \\
3 to $1 \mathrm{dmm}$ & 10 & 9.1009 & 0.9101 & 0.0245 \\
1 to $(-1) \mathrm{dmm}$ & 10 & 9.2110 & 0.9211 & 0.0284 \\
$(-1)$ to $(-3) \mathrm{dmm}$ & 10 & 9.2333 & 0.9233 & 0.0239 \\
$(-3)$ to $(-5) \mathrm{dmm}$ & 10 & 8.6000 & 0.8600 & 0.1071 \\
\hline Summary & Count & Sum & Mean & Variance \\
\hline $0^{\circ}$ & 10 & 6.7621 & 0.6762 & 0.1398 \\
$10^{\circ}$ & 10 & 6.3766 & 0.6377 & 0.1391 \\
$20^{\circ}$ & 10 & 6.0410 & 0.6041 & 0.1725 \\
$30^{\circ}$ & 10 & 6.9445 & 0.6945 & 0.1644 \\
$40^{\circ}$ & 7.5000 & 0.7500 & 0.1405 \\
$50^{\circ}$ & 10 & 8.5650 & 0.8565 & 0.0645 \\
$60^{\circ}$ & 10 & 9.5815 & 0.9582 & 0.0031 \\
$70^{\circ}$ & 10 & 9.1847 & 0.9185 & 0.0117 \\
$80^{\circ}$ & 10 & 9.4521 & 0.9452 & 0.0022 \\
$85^{\circ}$ & 10 & 3.2792 & 0.3279 & 0.0326 \\
\hline
\end{tabular}


Table 2. Combined influence of the cutting angle and the difference betwen diameters in graft success. All statistical analyzes were done using a significance factor of $95 \%(p \leq 0.05)$. ANOVA summary tables ( $1 \mathrm{dmm}$ is a tenths of a millimeter, $10^{-4} \mathrm{~m}$ ). The result of the analysis ANOVA (two factors without replication) indicates that the statistical value of " $F$ " is much higher than the critical value for " $F$ " for both factors: angles and differences between diameters. Therefore, we can assure that the results of our tests are significant.

\begin{tabular}{|c|c|c|c|c|c|c|}
\hline \multicolumn{7}{|c|}{ ANOVA } \\
\hline $\begin{array}{c}\text { Sourface of } \\
\text { Variation }\end{array}$ & $\begin{array}{l}\text { Sum of } \\
\text { Squares }\end{array}$ & $\begin{array}{l}\text { Degrees of } \\
\text { Freedom }\end{array}$ & $\begin{array}{l}\text { Mean of the } \\
\text { Squares }\end{array}$ & F & $\begin{array}{l}\text { Probability } \\
\text { Value }\end{array}$ & $\begin{array}{c}\text { Critical } \\
\text { Value for F }\end{array}$ \\
\hline Diameter difference & 4.7160 & 9.0000 & 0.5240 & 13.6138 & 0.0000 & 1.9976 \\
\hline Cutting angle & 3.4002 & 9.0000 & 0.3778 & 9.8154 & 0.0000 & 1.9976 \\
\hline Error & 3.1178 & 81.0000 & 0.0385 & & & \\
\hline Total & 11.2340 & 99.0000 & & & & \\
\hline
\end{tabular}

After running the ANOVA analysis, the null hypotheses $\mathrm{H} 0$ were rejected for both cases, and the alternative hypotheses $\mathrm{Hi}$ were accepted. Therefore, confirmable cases of significant differences between success means and cutting angles and seedling diametric differences were observed with a 95\% confidence. To compare the differences, post-hoc rank tests were conducted to determine which means differ from each other. Student's $t$-type comparison tests (RCBD ANOVA and $t$-test) were performed (Table 3).

Table 3. Comparison of means differences between angles using Student's $t$-test ( $t$-test). Use of contrasts to determine whether there is a significant difference $(p \leq 0.05)$.

\begin{tabular}{|c|c|c|c|c|c|c|c|c|c|c|}
\hline & $0^{\circ}$ & $10^{\circ}$ & $20^{\circ}$ & $30^{\circ}$ & $40^{\circ}$ & $50^{\circ}$ & $60^{\circ}$ & $70^{\circ}$ & $80^{\circ}$ & $85^{\circ}$ \\
\hline $0^{\circ}$ & & $\mathrm{N}$ & $\mathrm{N}$ & $\mathrm{N}$ & $\mathrm{N}$ & $\mathrm{Y}$ & $\mathrm{Y}$ & $\mathrm{Y}$ & $\mathrm{Y}$ & $\mathrm{Y}$ \\
\hline $10^{\circ}$ & & & $\mathrm{N}$ & $\mathrm{N}$ & $\mathrm{N}$ & Y & Y & Y & Y & Y \\
\hline $20^{\circ}$ & & & & $\mathrm{N}$ & $\mathrm{N}$ & Y & Y & Y & Y & $\mathrm{N}$ \\
\hline $30^{\circ}$ & & & & & $\mathrm{N}$ & $\mathrm{N}$ & $\mathrm{N}$ & $\mathrm{N}$ & $\mathrm{N}$ & $Y$ \\
\hline $40^{\circ}$ & & & & & & $\mathrm{N}$ & $\mathrm{N}$ & $\mathrm{N}$ & $\mathrm{N}$ & Y \\
\hline $50^{\circ}$ & & & & & & & $\mathrm{N}$ & $\mathrm{N}$ & $\mathrm{N}$ & Y \\
\hline $60^{\circ}$ & & & & & & & & $\mathrm{N}$ & $\mathrm{N}$ & $Y$ \\
\hline $70^{\circ}$ & & & & & & & & & $\mathrm{N}$ & Y \\
\hline $80^{\circ}$ & & & & & & & & & & Y \\
\hline $85^{\circ}$ & & & & & & & & & & \\
\hline
\end{tabular}

Significant differences in the mean grafting success values were not observed for similar angles, whereas clearly significant differences were observed when larger angles were compared, especially for angles equal to $20^{\circ}$ or less and angles equal to $50^{\circ}$ or greater. A cutting angle of $85^{\circ}$ produced significant differences in the mean grafting success compared with most angles, including angles close to each other and distant, since the response of grafting success to cutting angle was random and irregular (Table 4).

Variations in the diameters of grafting seedlings greater than $90 \mathrm{cmm}$ produced significant differences in the mean success with respect to the other variations in diameter, which may be due to a random and unpredictable response to the success of the graft from these diametric differences. The remaining variations in diameters below $90 \mathrm{cmm}$ did not produce significant differences between their success means. 
Table 4. Comparison of means differences between diameter of seedlings using Student's $t$-test $(1 \mathrm{dmm}$ is a tenths of a millimeter, $\left.10^{-4} \mathrm{~m}\right)$. Use of contrasts to determine whether there is a significant difference $(p \leq 0.05)$.

\begin{tabular}{|c|c|c|c|c|c|c|c|c|c|c|}
\hline & 15 to $13 \mathrm{dmm}$ & 13 to $11 \mathrm{dmm}$ & 11 to $9 \mathrm{dmm}$ & 9 to $7 \mathrm{dmm}$ & 7 to $5 \mathrm{dmm}$ & 5 to $3 \mathrm{dmm}$ & 3 to $1 \mathrm{dmm}$ & $\begin{array}{c}1 \text { to }(-1) \\
\text { dmm }\end{array}$ & $\begin{array}{c}(-1) \text { to } \\
(-3) \mathrm{dmm}\end{array}$ & $\begin{array}{c}(-3) \text { to } \\
(-5) \mathrm{dmm}\end{array}$ \\
\hline 15 to $13 \mathrm{dmm}$ & & $\mathrm{N}$ & $\mathrm{Y}$ & $\mathrm{Y}$ & $\mathrm{Y}$ & $\mathrm{Y}$ & $\mathrm{Y}$ & $\mathrm{Y}$ & Y & $\mathrm{Y}$ \\
\hline 13 to $11 \mathrm{dmm}$ & & & Y & $\mathrm{Y}$ & $\mathrm{Y}$ & $\mathrm{Y}$ & Y & Y & $\mathrm{Y}$ & $\mathrm{Y}$ \\
\hline 11 to $9 \mathrm{dmm}$ & & & & Y & $\mathrm{Y}$ & $\mathrm{Y}$ & Y & Y & Y & Y \\
\hline 9 to $7 \mathrm{dmm}$ & & & & & $\mathrm{N}$ & Y & Y & $\mathrm{Y}$ & Y & $\mathrm{N}$ \\
\hline 7 to $5 \mathrm{dmm}$ & & & & & & $\mathrm{N}$ & $\mathrm{N}$ & Y & $\mathrm{N}$ & $\mathrm{N}$ \\
\hline 5 to $3 \mathrm{dmm}$ & & & & & & & $\mathrm{N}$ & $\mathrm{N}$ & $\mathrm{N}$ & $\mathrm{N}$ \\
\hline 3 to $1 \mathrm{dmm}$ & & & & & & & & $\mathrm{N}$ & $\mathrm{N}$ & $\mathrm{N}$ \\
\hline 1 to $(-1) \mathrm{dmm}$ & & & & & & & & & $\mathrm{N}$ & $\mathrm{N}$ \\
\hline $\begin{array}{c}(-1) \text { to }(-3) \\
\text { dmm }\end{array}$ & & & & & & & & & & $\mathrm{N}$ \\
\hline $\begin{array}{l}\text { (-3) to }(-5) \\
\text { dmm }\end{array}$ & & & & & & & & & & \\
\hline
\end{tabular}

\section{Conclusions}

A review of the scientific literature suggests that the success of the splice grafting process increases as the cutting angle increases as long as the union is based on similarities between the stems of the grafting seedlings. However, until now, the success rate based on the interaction between the cutting angle and diameter of the seedling has not been reported.

The present study has concluded that the success of a graft depends to a great extent on the cutting angle and diameter of the seedlings, with disparities or similarities between the seedling sections playing an important role in the success of smaller cutting angles, although the stem diameter shows decreasing importance as the cutting angle increases, with the minimum influence of diameter observed within a cutting angle range of $50^{\circ}$ and $70^{\circ}$.

Consequently, using the splicing technique with a cutting angle between $50^{\circ}$ and $70^{\circ}$ can lead to a substantial improvement of grafting conditions and techniques and can eliminate, to some extent, the random factor of differences between diameters as well as the pre-selection and matching requirements for sections between seedlings, thereby simplifying the demands for manual, automated and robotized grafting systems.

Author Contributions: J.-L.P.-A. conceived and designed the experiments, performed the experiments, collected, analyzed the data and interpreted the results, and developed the manuscript. A.C.-O. conceived and designed the experiments, analyzed the data, interpreted the results, and developed the manuscript. C.-C.M.-G. conceived and designed the experiments and performed the experiments. A.-J.C.-F. provided constructive suggestions on experiment analysis.

Acknowledgments: This study was supported by Tenova, Technological Center: Foundation for Auxiliary Technologies for Agriculture. The authors would like to acknowledge to all the employees involved for their contributions to experimental setting and data collection.

Conflicts of Interest: The authors declare no conflict of interest.

\section{References}

1. Pina, A.Y.; Errea, P. A review of new advances in mechanism of graft compatibility-incompatibility. Sci. Hortic. 2005, 106, 1-11. [CrossRef]

2. Mudge, K.; Janick, J.; Scoffield, S.; Goldschmidt, E.E. A history of grafting. Hortic. Rev. 2009, 35, 437-494. [CrossRef]

3. Hartmann, H.T.; Kester, D.E.; Davies, F.T.; Geneve, R.L. Principles of grafting and budding. In Plant Propagation. Principles and Practices, 8th ed.; Pearson: London, UK, 2010; Chapter 11; ISBN 978-0-13-501449-3.

4. Hartman, G.; Pawlowski, M.; Herman, T.; Eastburn, D. Organically Grown Soybean Production in the USA: Constraints and Management of Pathogens and Insect Pests. Agronomy 2016, 6, 16. [CrossRef]

5. Diacono, M.; Persiani, A.; Fiore, A.; Montemurro, F.; Canali, S. Agro-Ecology for Potential Adaptation of Horticultural Systems to Climate Change: Agronomic and Energetic Performance Evaluation. Agronomy 2017, 7, 35. [CrossRef]

6. Pradeep, K.; Youssef, R.; Mariateresa, C.; Giuseppe, C. Vegetable Grafting as a Tool to Improve Drought Resistance and Water Use Efficiency. Front. Plant Sci. 2017, 8, 1130. 
7. Moore, R. A model for graft compatibility-incompatibility in higher plants. Am. J. Bot. 1984, 71, 751-758. [CrossRef]

8. De Miguel, A.; Cebolla, V. Terralia 53, Pages 50-60. Octubre 2005. Unión del Injerto. Available online: https: / / www.terralia.com/terralias/view_report?magazine_report_id=365 (accessed on 1 September 2018).

9. Acosta Muñoz, A. La Técnica del Injerto en Plantas Hortícolas. Horticom (Extra Viveros I), Extra 2005. pp. 62-65. Available online: http:/ / bit.do/eAgQc (accessed on 15 September 2018).

10. Saravana Kumar, R.M.; Gao, L.X.; Yuan, H.W.; Xu, D.B.; Liang, Z.; Tao, S.C.; Guo, W.B.; Yan, D.L.; Zheng, B.S.; Edqvist, J. Auxin enhances grafting success in Carya cathayensis (Chinese hickory). Planta 2018, 247, 761-772. [CrossRef]

11. Melnyk, C.W. Plant grafting: Insights into tissue regeneration. Regeneration 2017, 4, 3-14. [CrossRef]

12. De Velasco Alvarado, M.J. Tesis: Anatomía y Manejo Agronómico de Plantas Injertadas en Jitomate. Universidad Autónoma de Chapingo (Mexico), 2013. Available online: https:/ / chapingo.mx/horticultura/ pdf/tesis/TESISMCH2013050810128186.pdf (accessed on 15 September 2018).

13. Leonardi, C.; Romano, D. Recent issues on vegetable grafting. Acta Hortic. 2004, 631, 163-174. [CrossRef]

14. Yang, S.; Xiang, G.; Zhang, S.; Lou, C. Electrical resistance as a measure of graft union. J. Plant Physiol. 1993, 141, 98-104. [CrossRef]

15. Bletsos, F.A.; Olympios, C.M. Rootstocks and Grafting of Tomatoes, Peppers and Eggplants for Soil-borne Disease Resistance, Improved Yield and Quality. 2008. Available online: http://www.globalsciencebooks.info/Online/ GSBOnline/images/0812/EJPSB_2(SI1)/EJPSB_2(SI1)62-73o.pdf (accessed on 15 September 2018).

16. Torii, T.; Kasiwazaki, M.; Okamoto, T.; Kitani, O. Evaluation of graft-take using a thermal camera. Acta Hortic. 1992, 319, 631-634. [CrossRef]

17. Oda, M.; Maruyama, M.; Mori, G. Water Transfer at Graft Union of Tomato Plants Grafted onto Solanum Rootstocks. J. Jpn. Soc. Hortic. Sci. 2005, 74, 458-463. [CrossRef]

18. De Miguel, A.; Cebolla, V. Terralia 53, Pages 50-60. Octubre 2005. Unión del Injerto.

19. Bausher, M.G. Road, South Rock, Pierce, Fort Graft Angle and Its Relationship to Tomato Plant Survival. Hort Sci. 2013, 48, 34-36. Available online: http://hortsci.ashspublications.org/content/48/1/34.short (accessed on 15 September 2018).

20. Turquois, N.; Malone, M. Non-destructive assessment of developing hydraulic connections in the graft union of tomato. J. Exp. Bot. 1996, 47, 701-707. [CrossRef]

21. Xia, Y.; Sarafis, V.; Campbell, E.O.; Callaghan, P.T. Non invasive imaging of water flow in plants by NMR microscopy. Protoplasma 1993, 173, 170-176. [CrossRef]

22. Mutisya, S.; Saidi, M.; Opiyo, A.; Ngouajio, M.; Martin, T. Synergistic Effects of Agronet Covers and Companion Cropping on Reducing Whitefly Infestation and Improving Yield of Open Field-Grown Tomatoes. Agronomy 2016, 6, 42. [CrossRef]

23. Lee, J.-M.; Kubota, C.; Tsao, S.J.; Bie, Z.; Echevarria, P.H.; Morra, L.; Oda, M. Current status of vegetable grafting: Diffusion, grafting techniques, automation. Sci. Hortic. 2010, 127, 93-105. [CrossRef]

24. Tian, S.; Xu, D. Current status of grafting robot for vegetable. In Proceedings of the 2011 International Conference on Electronic \& Mechanical Engineering and Information Technology, Harbin, China, 12-14 August 2011; Volume 4, pp. 1954-1957. [CrossRef]

25. Ito, T. Present state of transplant production practices in Japanese horticultural industry. In Proceedings of the International Symposium on Transplant Production Systems, Transplantant Production Systems, Yokohama, Japan, 21-26 July 1992; Kurata, K., Kozai, T., Eds.; Kluwer Academic Publishers: Amsterdam, The Netherlands, 1992. Available online: http:/ / www.springer.com/us/book/9780792317975 (accessed on 15 September 2018).

26. Lee, J.-M.; Oda, M. Grafting of Herbaceous Vegetable and Ornamental Crops. Hortic. Rev. 2003, 28. [CrossRef]

27. Nishiura, Y.; Murase, H.; Honami, N.; Taira, T. Devlopment of Plug-in Grafting Robotic System Osaka Prefecture University. In Proceedings of the IEEE Lnternatlonal Conference on Robotics and Automatlon, Nagoya, Japan, 25-27 May 1995; pp. 2510-2517. Available online: http://ieeexplore.iee.org/abstract/ document/525636/ (accessed on 15 September 2018).

28. Oda, M. Grafting of Vegetable Crops. Osaka Perfecture Univ. 2002, 54, 49-72. Available online: http:/ / repository. osakafu-u.ac.jp/dspace/bitstream/10466/1053/1/KJ00000052064.pdf (accessed on 15 September 2018).

29. Oda, M. Use of Grafted Seedlings for Vegetable Production in Japan. Acta Hortic. 2008, 770, 15-20. Available online: https:/ / www.actahort.org/books/770/770_1.htm (accessed on 15 September 2018). [CrossRef] 
30. Lee, J.-M.; Bang, H.J.; Ham, H.S. Grafting of Vegetables. Jpn. Soc. Agric. Mach. Food Eng. 1998, 67, 1098-1104. Available online: https://www.jstage.jst.go.jp/article/jjshs1925/67/6/67_6_1098/_pdf (accessed on 15 September 2018). [CrossRef]

31. Singh, H.; Kumar, P.; Chaudhari, S.; Edelstein, M. Tomato Grafting: A Global Perspective. HortScience 2017, 52, 1328-1336. [CrossRef]

32. Same as 49 Miles, C.; Flores, M.; Estrada, E. Hoja de Datos de la Extensión, FS052ES. INJERTO de Verduras Berenjenas y Tomates; Washington State University: Washington, DC, USA, 2013; pp. 1-4. Available online: http:/ / cru.cahe.wsu.edu/CEPublications/FS052ES/FS052ES.pdf (accessed on 15 September 2018).

33. Same as 52 De Miguel Gómez, A. Serie Documentos: El Injerto de Plantas de Tomate. Postcosecha 2011, Www.poscosecha.com-Postharvest, Www.postharvest.biz. Available online: www.poscosecha.com/es/ publicaciones / (accessed on 15 September 2018).

34. Alvarez, C.; Herzog, D. La técnica del injerto (Presentation by Rijk Zwaan Ibérica). Rijk Zwaan Ibérica, 2011. Available online: https:/ / es.slideshare.net/directorarica/presentacin-injerto-semilleros (accessed on 15 September 2018).

35. Oda, M. Grafting of Vegetables to Improve Greenhouse Production; Food \& Fertilizer Technology Center: Kawana, Japan, 1998; pp. 1-11. Available online: http:/ / www.agnet.org/library.php?func=view\&id=20110803135029 (accessed on 15 September 2018).

36. Villasana Rojas, J.A. Tesis: Efecto del Injerto en la Producción de Tomate (Lycopersicon esculentum Mill.) Bajo Condiciones de Invernadero en Nuevo León; Universidad Autónoma de Nuevo León: San Nicolás de los Garza, Mexico, 2010; Available online: http:/ / eprints.uanl.mx/5613/1/1080194762\%20\%281\%29.PDF (accessed on 15 September 2018).

37. Yamada, H. Research for Development of the Grafting Robot for Solanaceae. Tech. Pap. Agric. Mach. Res. Assoc. 2003, 65, 142-149. Available online: https://www.jstage.jst.go.jp/article/jsam1937/65/5/65_5_ 142/_pdf/-char/ja (accessed on 15 September 2018).

38. Oda, M.; Tsuji, K.; Sasaki, H. Effect of Hypocotyl Morphology on Survival Rate and Growth of Cucumber Seedling Grafted on Cucurbita ssp. Japan Agricultural Research Quarterly. 1993. Available online: http: / / www.jircas.affrc.go.jp/english/publication/jarq/26-4/26-4-259-263.pdf (accessed on 15 September 2018).

39. Same as 46 Oda, M. Vegetable seedling grafting in Japan. Acta Hortic. 2007, 759, 175-180.

40. Ashraf, M.A.; Kondo, N.; Shiigi, T. Use of Machine Vision to Sort Tomato Seedlings for Grafting Robot. Eng. Agric. Environ. Food 2011, 4, 119-125. [CrossRef]

41. Tian, S.; Ashraf, M.A.; Kondo, N.; Shiigi, T.; Momin, M.A. Optimization of Machine Vision for Tomato Grafting Robot. Sens. Lett. 2013, 11, 1190-1194. [CrossRef]

42. Division, P.B.; Crops, O. Use of Rootstocks in Solanaceous Fruit-Vegetable Production in Japan Plant Breed; JIRCIS: Tsukuba, Japan, 1980.

43. Camacho Ferre, F.; (Coordinador Obra). V. autores. Técnicas de Producción de Cultivos Protegidos. Tomo II. Caja Rural Intermediterránea, Instituto Cajamar. Ediciones Agrotécnicas, S.L.; II, 776. 2003. Available online: http://www.publicacionescajamar.es/pdf/series-tematicas/agricultura/tecnicas-deproduccion-en-cultivos.pdf (accessed on 15 September 2018).

44. Gaion, L.A.; Braz, L.T.; Carvalho, R.F. Grafting in Vegetable Crops: A Great Technique for Agriculture. Int. J. Veg. Sci. 2017, 1-18. [CrossRef]

45. Montsanto, De Ruiter Product guide. Rut. Prod. Guid. 2012. Available online: http:/ /www.deruiterseedstemp.com/ global/au/products/Documents/DeRuiterAUProductGuide.pdf (accessed on 15 September 2018).

46. Johnson, S.; Kreider, P.; Miles, C. Vegetable Grafting: Eggplants and Tomatoes. 2013. Available online: http:// extension.wsu.edu/publications/wp-content/uploads/sites/54/publications/fs052e.pdf (accessed on 15 September 2018). Washington State Univ.; WSU Mount Vernon Northwestern Washington, Fact Sheet, 1-6.

47. Rivard, C.L.; Louws, F.J. Grafting for Disease Resistance in Heirloom Tomatoes; AG-675; North Carolina Cooperative Extension Service: Raleigh, NC, USA, 2007; pp. 1-8.

48. Bumgarner, N.R.; Kleinhenz, M.D. Grafting Guide: A Pictorial Guide to the Cleft and Splice Graft Methods as Applied to Tomato and Pepper. Ohio State University. Research and Development Center, 2014. Available online: http:/ /web.extension.illinois.edu/smallfarm/downloads/50570.pdf (accessed on 15 September 2018).

49. Oda, M. New Grafting Methods for Fruit-Bearing Vegetables in Japan. Jpn. Agric. Res. Q. 1995, 194, $187-194$.

50. Maurya, A.K. Role of Grafting in vegetable Production. Vegetable Grafting. GB Pant University of Agriculture and Technology, Pantnagar Uttarakhand, 2014. Available online: http://es.slideshare.net/ ashish7891/vegetable-grafting (accessed on 15 September 2018). 
51. Oda, M. Grafting of Vegetables to Improve Greenhouse Production, p. 1-11. Extension Bulletin—Food \& Fertilizer Technology Center, 1999. Available online: https://es.scribd.com/document/220401141/Veggie-Grafting (accessed on 15 September 2018).

52. Torres, A.P.; Lopez, G.R. Medición de Luz Diaria Integrada en Invernaderos. Purdue Agriculture. Available online: https:/ /www.extension.purdue.edu/extmedia/HO/HO-238-SW.pdf (accessed on 15 September 2018).

53. Kubota, C.; McClure, M.A.; Kokalis-Burelle, N.; Bausher, M.G.; Rosskopf, E.N. Vegetable grafting: History, use, and current technology status in North America. Hortscience 2008, 43, 1664-1669.

54. Velasco-alvarado, M.D.J.; Castro-brindis, R.; Avitia-garcía, E.; Castillo-gonzáles, A.M.; Sahagún, J. Proceso de unión del injerto de empalme en jitomate (Solanum lycopersicum L.). Revista Mexicana de Ciencias Agrícolas. 2017. Available online: http:/ / www.redalyc.org/html/2631/263152411004/ (accessed on 15 September 2018).

55. Andrews, P.K.; Marquez, C. Graft incompatibility. Hortic. Rev. 1993, 1, 183-232.

56. De Miguel, Alfredo II Jornadas Sobre Semillas y Semilleros Hortícolas. Libro Editado: ISBN: 84-87564-40-2 1997, 216. Available online: http:/ / www.juntadeandalucia.es/export/drupaljda/1337170141IIJornadas_sobre_Semillas_y_ Semilleros_Horticolas_BAJA.pdf (accessed on 15 September 2018).

57. Tateishi, K. Grafting Watermelon onto Pumpkin Suggested Potential Applications. Available online: https://pdfs. semanticscholar.org/2d91/f2d762af27589ecffd858c5eed25bd98ad93.pdf (accessed on 15 September 2018).

58. Zhao, X. Grading system of tomato grafting machine based on machine vision. In Proceedings of the 8th International Congress on Image and Signal Processing, Shenyang, China, 14-16 October 2015; pp. 604-609. Available online: http:/ / ieeexplore.ieee.org/document/7407950/ (accessed on 15 September 2018).

(C) 2018 by the authors. Licensee MDPI, Basel, Switzerland. This article is an open access article distributed under the terms and conditions of the Creative Commons Attribution (CC BY) license (http:/ / creativecommons.org/licenses/by/4.0/). 